\title{
Comparative Study between Combined Sciatic-Femoral Nerve Block, via a Single Skin Injection, and Spinal Block Anesthesia for Unilateral Surgery of the Lower Limb
}

\author{
Luiz Eduardo Imbelloni, TSA ${ }^{1}$, Gustavo Volpato Passarini de Rezende 2, Eliana Marisa Ganem, TSA ${ }^{\text {, }}$ \\ José Antonio Cordeiro ${ }^{4}$
}

Summary: Imbelloni LE, Rezende GVP, Ganem EM, Cordeiro JA - Comparative Study between Combined Sciatic-Femoral Nerve Block, via a Single Skin Injection, and Spinal Block Anesthesia for Unilateral Surgery of the Lower Limb.

Background and objectives: Unilateral spinal anesthesia has advantages when used in outpatient basis. The objective of the present study was to compare unilateral spinal anesthesia with combined sciatic-femoral nerve block in unilateral orthopedic surgeries in outpatients.

Methods: Sixty patients were randomly divided into two groups of 30 patients to receive $6 \mathrm{mg}$ of hyperbaric or hypobaric bupivacaine (RQ group) in left lateral decubitus, or $800 \mathrm{mg}$ of $1.6 \%$ lidocaine with epinephrine on sciatic and femoral nerves (CFI group) in dorsal decubitus. A 150-mm needle connected to a neurostimulator, inserted in the middle point between both classical approaches, was used for the nerve block, with the injection of $15 \mathrm{~mL}$ on the femoral nerve and $35 \mathrm{~mL}$ on the sciatic nerve. The time for the blockades and their duration were evaluated. After twenty minutes, patients were evaluated regarding the sensorial and motor blockades.

Results: Time for performance of spinal anesthesia was substantially lower than for combined sciatic-femoral nerve block. Unilateral blockade was achieved in $90 \%$ of the patients in the RQ group, and $100 \%$ in the CFI group. Bradycardia or hypotension was not observed.

Conclusions: This study concluded that combined sciatic-femoral nerve block is technically easy to perform and it can be an alternative for unilateral blockade of the lower limbs. Unilateral spinal anesthesia with low doses of bupivacaine resulted in shorter time to perform it, lower number of attempts, and earlier recovery than combined sciatic-femoral nerve block, but with the same efficacy.

Keywords: ANESTHETICS, Local: bupivacaine, lidocaine; ANESTHETIC TECHNIQUES, Regional: spinal anesthesia; femoral nerve block: sciatic nerve block; SURGERY, Orthopedic.

[Rev Bras Anestesiol 2010;60(6): 584-592] @Elsevier Editora Ltda.

\section{INTRODUCTION}

The increase in the number of outpatient procedures represents a challenge for the anesthesiologist to provide an effective and safe surgery with speedy patient discharge ${ }^{1}$. Due to its simplicity and safety, spinal anesthesia is a regional technique used in outpatient surgeries. Unilateral spinal anesthesia is known to minimize the cardiovascular effects of neuroaxis blockade ${ }^{2,3}$.

Unilateral anesthesia provided by the combined block of peripheral nerves of the lower limbs can be a safe and effective option for outpatient surgeries. Thus, anesthesia of the lower limbs requires injection of local anesthetic on femoral and sciatic nerves. Combined blockade of both nerves is used for surgeries of the knees and below, and the success rate,

Received from the Instituto de Anestesia Regional. Hospital Rio Laranjeiras, Rio de Janeiro, RJ, Brazil.

1. Anesthesiologist

2. Orthopedist of Hospital Rio Laranjeiras

3. Anesthesiologist - PhD, Assisting Professor of the Anesthesiology Department, Facul-

dade de Medicina de Botucatu, Universidade Estadual Paulista/UNESP, Brazil

4. PhD, Professor of Faculdade de Medicina de Rio Preto - FAMERP, São José do Rio

Preto, SP, Brazil

Submitted on March 2, 2010

Approved on June 4, 2010.

Correspondence to:

Dr. Luiz Eduardo Imbelloni

Av. Epitácio Pessoa, 2356/203

22411-072 - Rio de Janeiro, RJ

E-mail: dr.imbelloni@terra.com.br even in experienced hands, can be lower than that obtained with neuroaxis block 4,5 .

The objective of this randomized, prospective study was to evaluate the time required for performance of both blockades, effectivity, hemodynamic effects, toxic reactions, and conditions of discharge from the hospital of unilateral spinal anesthesia and combined sciatic-femoral nerve block for belowknee surgeries.

\section{METHODS}

After approval by the Ethics on Research Committee of the Faculdade de Medicina of São José do Rio Preto (FAMERP) and signing of the informed consent, patients were enrolled in this longitudinal prospective, randomized study with consecutive cohort. The size of the study population was estimated to detect the mean time to perform the blockades by, at least, one minute less by using unilateral spinal block anesthesia instead of combine sciatic-femoral nerve block based on a common standard deviation of no more than 1.2 minutes, with a power of $90 \%$, and significance level of $\alpha=0.05$, resulting in 26 patients in each group. Just to be on the safe side, four more patients were included in each group. Sixty patients, physical status ASA I and II (physical status according to the criteria of the American Society of Anesthesiologists), ages 
ranging from 20 to 60 years, weighing 45 to $90 \mathrm{~kg}$, height of 145 to $195 \mathrm{~cm}$, of both genders, scheduled for unilateral below-knee surgery, were included in the present study. Patients with cardiac or respiratory diseases, mental disorders, neurologic disorders, and sensitivity to the anesthetic or anticoagulant therapy, were excluded from the study.

Premedication was not used. Monitoring consisted of noninvasive blood pressure, heart rate, and pulse oximetry. After venous cannulation with a $20 \mathrm{G}$ catheter in the hand or forearm, fentanyl $1 \mu \mathrm{g} . \mathrm{kg}^{-1}$, and midazolam $1 \mathrm{mg}$, were administered before the anesthesia. All patients received Ringer's lactate infusion. Patients were randomly selected based on coded envelopes, specially prepared for the study, to receive unilateral spinal anesthesia (RG group) or combined sciaticfemoral nerve block (CFI group).

In the $R Q$ group, with the patient in left lateral decubitus, subarachnoid puncture was performed in the $L_{3}-L_{4}$ intervertebral space with a $27 \mathrm{G}$ Quincke needle (B. Braun, Melsungen S.A.) without introducer, using the paramedian approach, after anesthesia of the needle trajectory with $1 \%$ lidocaine. After free flow of cerebrospinal fluid (CSF), the bevel of the needle was directed towards the dependent side and $6 \mathrm{mg}$ $(1.2 \mathrm{~mL}$ ) of hyperbaric $0.5 \%$ bupivacaine (surgery in the left lower limb) over $30 \mathrm{sec}$, or $6 \mathrm{mg}(4 \mathrm{~mL})$ of $0.15 \%$ hypobaric bupivacaine (surgery in the right lower limb) over $60 \mathrm{sec}$, were injected (Cristália Produtos Químicos e Farmacêuticos Ltda.). The number of attempts to access the subarachnoid space was evaluated. Patients were maintained in this position for 20 minutes and posteriorly placed in dorsal decubitus.

In the CFI group, the sciatic-femoral nerve block was performed with the patient in dorsal decubitus with only one puncture site, according to the technique described by Pandin et al. 6 (Figure 1), after anesthesia of the trajectory of both nerves with $1 \%$ lidocaine, using $50 \mathrm{~mL}$ of $1.6 \%$ lidocaine with epine-

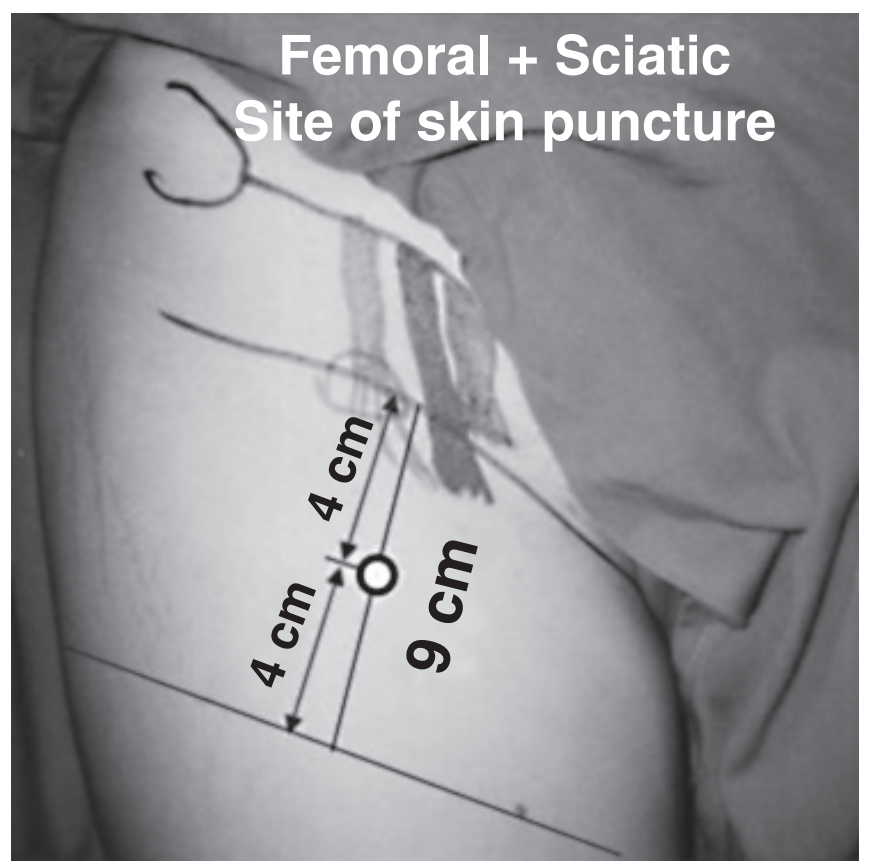

Figure 1 - Diagram for Insertion of the Needle. phrine 1:200,000 (2\% lidocaine $=40 \mathrm{~mL}+$ bidistilled water $=$ $10 \mathrm{~mL}$ ) (Cristália Produtos Químicos e Farmacêuticos Ltda.). Both nerves were identified by a $150-\mathrm{mm}$ long $22 \mathrm{G}$ short-beveled needle (B. Braun, Melsungen AG, Germany) connected to a HNS 12 Stimuplex stimulator (B. Braun, Melsungen AG, Germany). The frequency of stimulation used was $2 \mathrm{~Hz}$, with an intensity of $0.6 \mathrm{~mA}$ during $0.3 \mathrm{msec}$. The blockade was performed advancing the needle at a $45^{\circ}$ cephalad angle and $10^{\circ}$ laterally to the femoral artery until movement of the patella was observed after femoral stimulation; then, $15 \mathrm{~mL}$ of the anesthetic solution were injected. Afterwards, the needle was removed until the subcutaneous tissue and redirected $10^{\circ}$ laterally and $80^{\circ}$ posteriorly. With a depth of $8-15 \mathrm{~cm}$, the sciatic nerve was identified by stimulation of the common fibular nerve (dorsiflexion or eversion of the foot) or tibial nerve (plantar flexion or inversion of the foot and flexion of the toes) and 35 $\mathrm{mL}$ of the anesthetic solution were administered. The number of attempts to localize the femoral nerve (patellar contraction) and sciatic nerve (foot contraction) were evaluated.

The time to perform the regional anesthesia was evaluated in both groups. Twenty minutes after the local anesthetic was injected, with the patient in dorsal decubitus, the sensorial and motor blockades were investigated in the limb to be operated and in the contralateral limb. The sensorial blockade was evaluated by the loss of cold and pain (pinprick) sensations bilaterally, in the $R Q$ group, and on the different paths of the femoral, lateral cutaneous, obturator, common fibular, and tibial nerves, in the CFI group. The motor blockade was evaluated by the modified Bromage scale ${ }^{7}(0=$ absence of blockade; 1 = blocked thigh; 2 = hip and knee blocked; 3 = hip, knee, and ankle blocked).

Cardiorespiratory parameters were measured every 5 minutes, during the first 20 minutes after installation of the blockade, followed by every 10 minutes until the end of the procedure. Hypotension (a reduction in SBP > 30\% when compared to the pressure in the regular ward) was treated with etilefrine (2 mg IV), while bradycardia (HR $<45 \mathrm{bpm}$ ) was treated with atropine $(0.50 \mathrm{mg} I \mathrm{~V})$.

The time between the injection of anesthetic and the end of the surgery was recorded. The quality of the blockade was assessed according to the need of supplementation of intravenous analgesic: adequate blockade (without supplementation); inadequate blockade (need of fentanyl $1 \mu \mathrm{g} . \mathrm{kg}^{-1}$ to finish the surgery); failed block (need of general anesthesia to finish the surgery).

Data regarding the time between the injection and complete resolution of the sensorial and motor blockades, capacity of urinating, and neurologic complications were recorded.

Quantitative variables (age, weight, height, BMI, times: to perform, duration of the surgery, and duration of the sensorial and motor blockades) are presented as mean (standard deviation) and compared by the t-test for two samples with Welch correction for the degrees of freedom, or they are presented as median (iqa: interquartile amplitude), and compared by the Kruskal-Wallis test, when recommended. Qualitative variables of two levels (ASA, operated and non-operated blockades, pain on garroting, gender) were analyzed by Pearson's 
Chi-square test or Fisher exact test, when appropriate, while those with three or more levels, by the likelihood-ratio Chisquare test for independent samples. A level of significance of $\alpha=0.05$ was adopted.

\section{RESULTS}

Differences in demographic parameters were not observed between both groups (Table I). In the RQ group, 16 patients were anesthetized with the hypobaric solution and 14 with hyperbaric solution of bupivacaine. All patients in the CFI group were anesthetized with $50 \mathrm{~mL}$ of $1.6 \%$ lidocaine with epinephrine.

In the RQ group, the subarachnoid space was accessed after one attempt in 23 patients, two attempts in five patients, and three attempts in two patients. In the CFI group, the femoral nerve was located in the first attempt in 26 patients, and after two attempts in four patients, while the sciatic nerve was located in the first attempt in 18 patients, after two attempts in seven patients, in three attempts in three patients, and in four attempts in two patients. A difference was not observed when spinal anesthesia was compared with femoral $(p=0.28)$ and sciatic $(p=0.14)$ nerve blocks. However, when the number of attempts for spinal anesthesia was compared with the combined sciatic-femoral nerve block, a higher number was observed for the CFI group ( $p<0.0005$, Kruskal-Wallis test). Failure to locate the subarachnoid space and the femoral and sciatic nerves was not observed.

The time to perform the spinal anesthesia, $1.1(0.3) \mathrm{mi}-$ nutes, was significantly lower $(p<0.0005)$ than to perform the combined sciatic-femoral nerve block, which was $5.4(0.9)$ minutes (Table II).

Table I - Demographic Variables, Qualitative and Quantitative

\begin{tabular}{llll}
\hline Variable & $\begin{array}{l}\text { RQ Group } \\
(\mathrm{n}=30)\end{array}$ & $\begin{array}{l}\text { CFI Group } \\
(\mathrm{n}=30)\end{array}$ & $\mathrm{p}$ \\
\hline Gender $(\mathrm{F} / \mathrm{M})$ & $15 / 15$ & $13 / 17$ & 0.60 \\
Age (years) & $40(12)$ & $39(10)$ & 0.70 \\
Weight $(\mathrm{kg})$ & $67(12)$ & $69(9)$ & 0.38 \\
Height $(\mathrm{cm})$ & $166(10)$ & $169(5)$ & 0.15 \\
BMI $\left(\mathrm{kg} \cdot \mathrm{m}^{2}\right)$ & $24(4)$ & $24(3)$ & 1.0 \\
ASA $(\mathrm{I} / \mathrm{II})$ & $14 / 16$ & $20 / 10$ & 0.11 \\
\hline
\end{tabular}

Mean and (SD).

Table II - Time to Perform the Anesthesia, Duration of the Surgery, Duration of the Sensorial Blockade, and Duration of the Motor Blockade

\begin{tabular}{llll}
\hline Variable & RQ Group & CFI Group & \\
\hline Time to perform $(\mathrm{min})$ & $1.1(0.3)$ & $5.4(0.9)$ & $<0.0005$ \\
Duration of the surgery $(\mathrm{h})$ & $1.4(0.2)$ & $1.3(0.2)$ & 0.36 \\
Duration of sensorial blockade $(\mathrm{h})$ & $2.7(0.3)$ & $4.1(0.7)$ & $<0.0005$ \\
Duration of motor blockade $(\mathrm{h})$ & $2.3(0.2)$ & $3.2(0.4)$ & $<0.0005$ \\
\hline
\end{tabular}

Mean and (SD).
The level of the sensorial blockade was $T_{10}$ in 10 patient, $T_{11} 1$ in 2 patients, and $T_{12}$ in 8 patients in the $R Q$ group in the operated limb, but in three patients the anesthetic also affected the contralateral limb. All patients in the $R Q$ group were successfully operated. In the CFI group, sensorial blockade of the femoral nerve was observed in all patients, of the lateral cutaneous nerve in 24 patients, obturator nerve in 24 patients, common fibular nerve in 28 patients, and tibial nerve in 28 patients. A 3-in-1 block was observed in $80 \%$ of the patients. Blockade of the contralateral limb was not observed in the CFI group.

A grade 3 motor blockade of the lower limbs was observed in all patients in the RQ group. In the CFI group, a grade 3 motor blockade was observed in 19 patients, while a grade 2 motor blockade was observed in 11 patients, with a statistically significant difference $(p<0.0005)$.

Adequate blockade was observed in all (100\%) patients in the $\mathrm{RQ}$ group. In the CFI group, adequate blockade was observed in $26(86 \%)$ patients, inadequate in two (7\%) patients, and failure in two $(7 \%)$ patients. A significant difference in the quality of the blockade was not observed $(p=0.23)$. No patient in the $R Q$ group complained of pain with the pneumatic tourniquet, while in the CFI group four patients complained of pain, but this difference was not statistically significant $(p=0.11)$.

The duration of the sensorial and motor blockades was significantly lower with spinal anesthesia when compared to the combined sciatic-femoral nerve block (Table II). A significant difference was not observed regarding the duration of the surgery (Table II).

Hypotension, bradycardia, or urinary retention was not observed in either group. Toxicity (seizures, arrhythmia, etc.) was not observed in the CFI group.

Patients in the RQ group did not complained of post-dural puncture headache. During the postoperative interview, patients did not complain of transitory neurologic symptoms or paresthesia or dysesthesia of the femoral and sciatic nerves after being discharged. Postoperative motor deficit was not observed in any patient. Patient satisfaction was similar in both groups $(p=0.23)$.

\section{DISCUSSION}

This study demonstrated that $6 \mathrm{mg}$ of hypobaric or hyperbaric bupivacaine can be used in unilateral surgeries of the lower limbs with a shorter time to perform the anesthesia, smaller number of attempts, shorter duration of anesthesia, and the same effectivity as the combined sciatic-femoral nerve block with $800 \mathrm{mg}$ of $1.6 \%$ lidocaine with epinephrine. Combined sciatic-femoral nerve block in the anterior region with a single injection site and with the aid of a peripheral nerve stimulator, is an easy technique and adverse effects were not observed.

Besides preventing hemodynamic changes, the objective of the unilateral block is to induce unilateral motor blockade, therefore improving patient comfort, since prolonged bilateral motor blockade can be inconvenient. This objective was 
achieved in $90 \%$ of the patients undergoing unilateral spinal block anesthesia and in $100 \%$ of those undergoing combined sciatic-femoral nerve block.

Knowledge of the anatomy is fundamental for the anesthesiologist to perform any technique of regional anesthesia, and the combined sciatic-femoral nerve block is not an exception. True 3-in-1 block was observed in $80 \%$ of the patients, which is lower than the $85.7 \%$ reported on the initial study that described the technique ${ }^{6}$. Complete sciatic block was obtained in $93.3 \%$, which is very close to the $94.9 \%$ reported by the same study ${ }^{6}$.

The maximal dose of lidocaine with epinephrine recommended for regional blocks in adults is $7 \mathrm{mg} \cdot \mathrm{kg}^{-18}$. The mean plasma concentration after the transarterial anesthesia of the brachial plexus with $900 \mathrm{mg}$ of lidocaine was $2.9 \mu \mathrm{g} \cdot \mathrm{mL}^{-1}$, with the higher individual value obtained of $5.6 \mu \mathrm{g} \cdot \mathrm{mL}^{-1}$, which represents a dose of $18 \mathrm{mg} \cdot \mathrm{kg}^{-1}$. The dose of $900 \mathrm{mg}$ used routinely in over 500 patients through the transarterial approach is $12.5 \%$ higher than the $800 \mathrm{mg}$ used in the present study. With $900 \mathrm{mg}$ of lidocaine ${ }^{9}$, clinical manifestations of systemic toxicity were not observed, and the same is true for the current study. The axillary approach of the brachial plexus with the multiple stimuli technique with 800 $\mathrm{mg}$ of $1.6 \%$ of lidocaine with epinephrine resulted in a success rate of $92.5 \%$ without adverse effects ${ }^{10}$. In this study, using the same dose of lidocaine, we obtained a success rate of $86.6 \%$ of blockade of both nerves.

High doses (12 to $20 \mathrm{mg}$ ) of bupivacaine in spinal anesthesia show important migration of the blockade, even with the patient remaining in the sitting position for one hour ${ }^{11}$, while small doses $(5-8 \mathrm{mg})$ of the same substance, with the patient remaining in the lateral position for 10 to 15 minutes ${ }^{12}$, resulted in restricted blockade. The best unilateral result was observed when using low dose of hyperbaric or hypobaric bupivacaine and the patient was maintained in lateral decubitus for 15-20 minutes ${ }^{13}$. In the present study, with $6 \mathrm{mg}$ of hyperbaric or hypobaric bupivacaine and maintaining the patient in lateral decubitus for 20 minutes, selective unilateral blockade was observed in $90 \%$ of the patients. As expected, combined sciatic-femoral nerve block resulted in selective unilateral blockade.

Small dose of the local anesthetic injected in the subarachnoid space causes minimal hemodynamic changes with great cardiovascular stability. Hypotension is a simple complication of spinal anesthesia, being observed in up to $33 \%$ of the patients when higher doses are used ${ }^{14}$. Unilateral block with either solution causes less hypotension. Comparing hemodynamic changes in unilateral and bilateral blocks using the same dose of hyperbaric bupivacaine $(8 \mathrm{mg})$, the incidence of hypotension was $22.4 \%$ and $5 \%$, respectively ${ }^{2}$. With $6 \mathrm{mg}$ of bupivacaine, hypotension was not observed; the same can be said for the combined sciatic-femoral nerve block.

In the initial study with the technique ${ }^{6}$, it took the authors a mean of 4.1 minutes to perform the combined sciaticfemoral nerve block. In both studies, the time to perform the combined sciatic-femoral nerve block was 4 to 5 times higher than for unilateral spinal anesthesia, which was $1.1 \mathrm{~min}$ utes. In the present study, patients in both groups remained in the position of the blockade for 20 minutes before they were evaluated. This was reflected in only 5 minutes delay for the beginning of the surgery when both techniques were compared.

Epinephrine prolongs the duration and intensity of the majority of local anesthetics used in peripheral nerve blocks. Adding epinephrine 1:200,000 (5 $\left.\mu \mathrm{g} \cdot \mathrm{mL}^{-1}\right)$ increases significantly the mean duration of lidocaine (264 minutes versus 186 minutes) ${ }^{15}$. This is due to vasoconstriction that prolongs the exposure of the nerve to the local anesthetic. The mean time of analgesia obtained with $1.6 \%$ lidocaine with epinephrine was 246 minutes, in combined sciatic-femoral nerve block, which was much higher than that for unilateral spinal anesthesia, which was 162 minutes.

Since one of the criteria for hospital discharge was recovery of the motor blockade, this was seen a mean of $3.2 \mathrm{~h} \mathrm{(192}$ minutes) in the combined sciatic-femoral nerve block, versus $2.3 \mathrm{~h}$ (138 minutes) in the spinal anesthesia, demonstratings that with spinal anesthesia the recovery time was significantly shorter, with higher chances of an early discharge.

This study concluded that, technically, the combined sciatic-femoral nerve block is easy to perform, and it can be an alternative for the unilateral surgery in the lower limbs when neuroaxis anesthesia is not indicated. Unilateral spinal anesthesia with low doses of bupivacaine resulted in less time to perform and for recovery with the same degree of effectiveness. 


\section{REFERÊNCIAS / REFERENCES}

01. White PF - Outpatient Anesthesia, em: Miller RD - Anesthesia, 3rd Ed, New York, Churchil-Livingstone, 1990;2025-2060.

02. Casati A, Fanelli G, Aldegheri G et al. - Frequency of hypotension during conventional or asymmetric hyperbaric spinal block. Reg Anesth Pain Med, 1999;24:214-219.

03. Kuusniemi KS, Pihlajamäki KK, Kirvelä OA et al. - Spinal anesthesia with hypobaric bupivacaine for knee arthroscopies: Effect of posture on motor block. Reg Anesth Pain Med, 2001;26:30-34.

04. Spasiano A, Flore I, Pesamosca A et al. - Comparison between spinal anaesthesia and sciatic-femoral block for arthroscopic knees surgery. Minerva Anestesiol, 2007;73:13-21.

05. Cappelleri G, Casati A, Fanelli G et al. - Unilateral spinal anesthesia or combined sciatic-femoral nerve block for day-case knee arthroscopy. A propesctive, randomized comparison. Minerva Anestesiol, 2000;66:131-136.

06. Pandin P, Vancutsem N, Salengros JC et al. - The anterior combined approach via a single skin injection site allows lower limb anesthesia in supine patients. Can J Anesth, 2003;50:801-804. 
07. Bromage PR - A comparison of the hydrochloride and carbon dioxide salts of lidocaine and prilocaine in epidural analgesia. Acta Anaesthesiol Scand, 1965;16(Suppl):55-69.

08. de Jong RH, Grazer FM - Perioperative management of cosmetic liposuction. Plast Reconstr Surg, 2001:107:1039-1044.

09. Palve $\mathrm{H}$, Kirvela $\mathrm{O}$, Olin $\mathrm{H}$ et al. - Maximum recommended doses of lignocaine are not toxic. Br J Anaesth, 1995;74:704-705.

10. Imbelloni LE, Beato L, Cordeiro JA - Comparação das técnicas transarterial e de estimulação de múltiplos nervos para bloqueio do plexo braquial por via axilar usando lidocaína com epinefrina. Rev Bras Anestesiol, 2005;55:40-49.

11. Povey HMR, Jacobsen J, Westergaard-Nielsen J - Subarachnoid analgesia with hyperbaric $0.5 \%$ bupivacaína: Effect of 60 -min period of sitting. Acta Anaesthesiol Scand, 1989;33:295-297.

12. Esmaoglu A, Boyaci A, Ersoy $O$ et al. - Unilateral spinal anesthesia with hyperbaric bupivacaine. Acta Anaesthesiol Scand, 1998;42:10831087.

13. Kuusniemi KS, Pihlajamäki KK, Pitkänen MT - A low dose of plain or hyperbaric bupivacaína for unilateral spinal anesthesia. Reg Anesth Pain Med, 2000;25:605-610.

14. Carpenter RL, Caplan RA, Brown DI et al. - Incidence and risk factors for side-effects of spinal anesthesia. Anesthesiology, 1992;76:906-916.

15. Bernards CM, Kopacz DJ - Effect of epinephrine on lidocaine clearance in vivo: A microdialysis study in humans. Anesthesiology, 1999;91:962-968.

Resumen: Imbelloni LE, Rezende GVP, Ganem EM, Cordeiro JA Estudio Comparativo del Bloqueo Combinado Femoral-Isquiático por Punción en Sitio Único, con Anestesia Subaracnoidea para Cirugías Unilateral del Miembro Inferior.
Justificativa y objetivos: La raquianestesia unilateral puede presentar ventajas en pacientes ambulatoriales. El objetivo de este trabajo fue comparar la raquianestesia unilateral con el bloqueo combinado femoral-isquiático en cirugías ortopédicas unilaterales y ambulatoriales.

Método: Sesenta pacientes fueron separados aleatoriamente en dos grupos de 30 para recibir $6 \mathrm{mg}$ de bupivacaína hiperbárica o hipobárica (grupo $R Q$ ), en decúbito lateral izquierdo u 800 mg de lidocaína $1,6 \%$ con epinefrina en los nervios femoral e isquiático (grupo CFI), en decúbito dorsal. El bloqueo de los nervios fue realizado con una aguja de $150 \mathrm{~mm}$ conectada a un neuroestimulador e insertada en el punto medio entre las dos incisiones clásicas. Se inyectaron $15 \mathrm{~mL}$ en el nervio femoral y $35 \mathrm{~mL}$ en el nervio isquiático. Fue mensurado el tiempo para la realización de los bloqueos y su duración. Veinte minutos después, los pacientes fueron evaluados con relación a los bloqueos sensitivo y motor.

Resultados: El tiempo para la realización de la raquianestesia fue significativamente menor que el bloqueo combinado femoral-isquiático. El bloqueo unilateral se obtuvo en un $90 \%$ de los pacientes en el grupo $R Q$ y en un $100 \%$ en el grupo CFI. El tiempo para la recuperación del bloqueo sensitivo y motor fue significativamente mayor en el grupo CFI. No hubo bradicardia o hipotensión.

Conclusiones: Por medio de este estudio, se llega a la conclusión de que es técnicamente fácil realizar el bloqueo anterior combinado femoral-isquiático y de que ese puede ser una alternativa para el bloqueo unilateral del miembro inferior. La raquianestesia unilateral con bajas dosis de bupivacaína, mostró un menor tiempo para la realización, un menor número de intentos y una recuperación más rápida del bloqueo combinado femoral-isquiático. Sin embargo, la efectividad fue la misma. 